\title{
Dwie przestrzenie wojennej propagandy. Język utworów moskiewskich Okien TASS
}

\author{
Two spheres of war propaganda. \\ The language of the Moscow TASS Windows' poems
}

\begin{abstract}
The aim of the article is to analyze the language of the Soviet propaganda posters from the Second World War period, containing the poetic commentary of the members of the Moscow TASS Agency. The research reveals the main means of persuasion used in the poems. The subject of the analysis is the phenomenon of spreading ideas in two basic social spheres that occurred in the Soviet Union during the war period, which include people who took direct part in military actions, and Soviet citizens who provided the army with all the necessary materials. Texts addressed to potential soldiers contained a direct call to defend the homeland and family. Their most important manipulative tools were emotional arguments and the technique of stereotyping the enemy. Ideas and personal patterns were instilled in the minds of the fighters with various linguistic manipulation techniques. The propaganda referenced to the belongingness need. Different propaganda techniques were used in poems targeted at people behind the lines of hostilities. The authors of the texts of TASS Windows used colloquial language, comprehensible to a wide audience. They created a vision of a world divided into two opposite poles and referred to respected authorities or raised new role models. The propaganda of the victory also required different techniques of information manipulation. The TASS Windows present the unique contribution of the Soviet poets to the action of the mobilization of society to take part in the fight against the German aggressor.
\end{abstract}

Keywords: TASS Windows, Soviet propaganda, agitation, persuasion, war poetry

Agata Książek, Uniwersytet Pedagogiczny im. Komisji Edukacji Narodowej w Krakowie, Kraków Polska, agata.ksiazek97@gmail.com, ORCID ID: https://orcid.org/0000-0001-9346-4899

Od kilku lat w badaniach lingwistycznych daje się zauważyć wzrost zainteresowania kwestią manipulacji językowej oraz technikami wywierania wpływu na szeroką grupę adresatów. Powstają synkretyczne poddziedziny nauki, oparte na osiągnięciach socjologii, politologii, psychologii oraz językoznawstwa, takie jak marketing polityczny, reklama wyborcza czy public relations. Nierzadko w analizie współczesnego dyskursu politycznego wykorzystywane jest pojęcie propagandy jako środka rozpowszechniania określonych idei oraz postaw. Nie- 
mniej jednak historia systemów totalitarnych XX wieku skłania wielu badaczy do zawężenia semantyki danego terminu do zorganizowanej działalności mającej na celu wszczepienie elementów ideologii w świadomość zbiorową społeczeństwa (Dubisz 404). W danym kontekście warto powrócić do analizy zagadnienia propagandy, które utrwaliło się w rosyjskiej tradycji językowej w odniesieniu do reżimu komunistycznego. Podstawowym kanałem komunikacji między partią rządzącą a społeczeństwem pozostawały w nim środki masowego przekazu, do których należą prasa, radio czy też plakat. Zwłaszcza na ostatni element warto zwrócić szczególną uwagę, jako że w ramach dzisiejszej dynamicznie rozwijającej się kultury graficznej często dochodzi do reprodukcji radzieckich plakatów agitacyjnych, dostosowanych do nowego kontekstu politycznego. Wystarczy przywołać liczne trawestacje dzieł Родина-мать завет!, Не болтай!, A ты записался добровольием? Celem niniejszego artykułu jest analiza środków propagandowych zastosowanych w wierszach plakatów okresu II wojny światowej utworzonych przez redakcję moskiewskiej agencji TASS (Telegraficzna Agencja Związku Radzieckiego). Badaniu poddane zostało zjawisko szerzenia idei w dwóch podstawowych grupach, do których należą: osoby podejmujące bezpośrednią aktywność na froncie oraz mieszkańcy pozostający na zapleczu działań wojennych. W trakcie analizy posłużyłam się metodologią pragmalingwistyczną, mając na uwadze, że skonstruowany odpowiednio tekst jest optymalnym narzędziem skutecznego oddziaływania na odbiorcę (nadawca kształtuje i kreuje sposób postrzegania, myślenia i zachowania odbiorcy), natomiast przy zestawieniu wyników badań wykorzystałam warsztat metodologii porównawczej oraz opisowej.

Okna TASS są to radzieckie plakaty agitacyjne wydawane w Moskwie w latach 1941-1945. W okresie wojennym ukazało się ponad 1200 plakatów, nad którymi pracowało ok. 130 plastyków i 80 poetów (Konopackaâ, Medne 444). Ich praca była swoistą kontynuacją tradycji słynnych Okien ROSTA, których czołowym twórcą był Włodzimierz Majakowski (Maslennikov 26). Okna TASS stanowiły artystyczną odpowiedź na tragiczne wydarzenia II wojny światowej. Satyry, bajki i pamflety wybitnych poetów, takich jak Diemjan Biedny, Samuił Marszak, jak również uroczyste hymny oraz ody Wasilija Lebiediewa-Kumacza i Aleksieja Maszystowa na stałe weszły do kanonu radzieckiej poezji wojennej. Jednocześnie dzięki wyjątkowo lakonicznej i ekspresywnej formie utwory te stały się znaczącym środkiem kształtowania opinii publicznej, a co ważniejsze - efektywnym narzędziem propagandy i agitacji.

Przystępując do analizy języka plakatów TASS, warto doprecyzować pojęcia kluczowe, takie jak propaganda, agitacja, perswazja oraz manipulacja, wykorzystywane do opisu języka polityki jako odmiany funkcjonalnej języka ogólnego. W danej kwestii szczególnie pomocne okazują się ustalenia terminologiczne Ireny Kamińskiej-Szmaj (Kamińska-Szmaj). Badaczka słusznie odnotowuje, że we 
współczesnej polszczyźnie funkcjonują dwa podstawowe znaczenia leksemu propaganda. W szerokiej definicji termin ten oznacza zorganizowane rozpowszechnianie idei, doktryn oraz teorii poprzez selektywny dobór treści komunikatu oraz zastosowanie metod wywierania wpływu w celu nakłonienia ludzi do zmiany postaw, poglądów lub podjęcia działań w interesie nadawcy. W wąskiej definicji propaganda pojmowana jest jedynie jako forma komunikowania politycznego polegająca na kierowaniu opinią publiczną. Kamińska-Szmaj zauważa, że o ile z propagandą związane jest wywieranie ideologicznego wpływu na adresata, o tyle celem agitacji jest pobudzanie do doraźnego działania poprzez aktywizowanie thumu środkami zarówno językowymi, jak i pozajęzykowymi. Wspomniana autorka podkreśla, że $\mathrm{w}$ analizie tekstów propagandowych często wykorzystywane jest również pojęcie perswazji, rozumianej jako wpływanie na poglądy adresata za pomocą mowy. Zasadniczą różnicę między perswazją i manipulacją widzi w spełnieniu lub naruszeniu warunku szczerości. W przeciwieństwie do pojęcia perswazji, które nie konotuje oceny, termin manipulacja ma negatywne nacechowanie emocjonalne i odnosi się do zamierzonego, ukrytego wpływu na postawę adresata w celu nakłonienia go do podjęcia działań, często niezgodnych z jego interesem.

Szczegółowym analizom języka propagandy wiele uwagi w swych pracach poświęca Jerzy Bralczyk. W monografii zatytułowanej $O$ języku propagandy i polityki badacz określa główny przedmiot i cel tekstów propagandowych - odpowiednio politykę i perswazję. Zdaniem językoznawcy, stworzenie jednolitej skali aksjologicznej w świecie propagandy jest możliwe dzięki jednoznacznemu wartościowaniu i ocenie zjawisk oraz postaw w życiu społecznym. Pomimo zewnętrznej szablonowości i ideologicznego przesycenia tekstów propagandowych Bralczyk zwraca uwagę na ich potencjał informacyjny. W konsekwencji wyróżnia trzy podstawowe funkcje tekstów propagandowych: informacyjną, rytualną i nakłaniającą (Bralczyk 30-34). Pierwsza dotyczy przekazywania informacji jako głównego aspektu komunikacji. Jednak w tekstach propagandowych informowanie przybiera bardziej skomplikowaną formę: celem nadawcy nie jest opis rzeczywistości, a jej formowanie. Odrzucenie kryterium adekwatności prowadzi do zniekształcenia rzetelności przekazu. Funkcja rytualna polega natomiast na stosowaniu stałych sformułowań. Język tekstów propagandowych jest tworem zinstytucjonalizowanym, opartym na frazeologizacji i wprowadzaniu do obiegu powtarzalnych nazw-etykietek. Nadawca, występując jako nosiciel wspólnej idei, przemawia w imieniu całej społeczności. Zastosowanie ujednoliconego kodu podnosi autorytet mówcy, co jest bezpośrednio powiązane z funkcją kontrolną. Wpływ na adresata realizuje się w ramach funkcji nakłaniającej tekstów propagandowych. Należy tu szczególnie zwrócić uwagę na różnicę pomiędzy dyrektywnością a perswazją. Pierwsza z nich odnosi się do określenia warunku lub żądania, druga posługuje się głównie ocenami. 
Funkcje tekstów propagandowych ustalone przez Bralczyka odzwierciedla model komunikacji perswazyjnej zaproponowany przez Lesława Wojtasika (Vojtasik 104). Na początku schematu znajduje się źródło informacji, w którego charakterze może występować członek organizacji lub partia ustalająca ideologiczne koordynaty. Kolejny etap polega na przekazaniu zakodowanej informacji (np. za pomocą środków masowego przekazu). Najbardziej rozbudowaną częścią modelu jest moment odbioru sygnału. Na danym etapie Wojtasik wyróżnia takie aspekty, jak skupienie uwagi odbiorcy, jego osobiste determinanty percepcji (w tym system stereotypów) oraz obecny stan emocjonalny. W ostatnim stadium dochodzi do utrwalenia informacji w pamięci odbiorcy i ewentualnej modyfikacji jego poglądów. Można zatem uznać, że podstawowym celem propagandy jest kształtowanie sposobu postrzegania świata przez człowieka jako jednostki jednolitej struktury społecznej. Stanowisko to różni się od teorii Bralczyka, jednak nie zaprzecza jej, gdyż perswazja zawsze zakłada istnienie docelowego systemu poglądów.

W modelu Wojtasika szczególnego znaczenia nabiera pojęcie stereotypu. Termin ten został wprowadzony do nauk społecznych na początku lat 20. XX wieku przez amerykańskiego dziennikarza Waltera Lippmanna, który zauważył istnienie uproszczonych sądów, niewynikających z osobistego doświadczenia rozmówcy (Lippmann 79-94). Wojtasik definiuje stereotypy jako stałe wyobrażenia o rzeczywistości, rozpowszechniane poprzez język lub obrazy w określonych grupach społecznych (Vojtasik 119). Wpływające na podświadome schematy wartościowania stereotypy determinują często nieadekwatny stosunek do zjawisk, osób, grup czy całych narodów. Warto podkreślić, iż źródłem formowania stereotypów może być właśnie przekaz propagandowy, utrwalający w świadomości zbiorowej narzucone przez polityków poglądy. Propaganda opiera się na myśleniu schematycznym, w którym każdemu elementowi rzeczywistości przypisane jest określone znaczenie.

Transformacja świadomości kolektywnej dokonuje się za pomocą różnych technik propagandowych. Tej kwestii szczególną uwagę poświęcają amerykańscy badacze. W latach 1937-1942 w Stanach Zjednoczonych funkcjonował Instytut Analiz Propagandy Uniwersytetu Columbia, którego przedstawicielem był amerykański dziennikarz i badacz języka polityki Clyde Raymond Miller. W jednej ze swoich prac wyróżnił on siedem podstawowych taktyk propagandy: etykietowanie (dobór stałych określeń, opartych na skojarzeniach i zawierających negatywną ocenę osób, grup lub zjawisk), piękne ogólniki (stosowanie pojęć o pozytywnych konotacjach, takich jak przyjaźń, wolność, demokracja), transfer (przeniesienie autorytetu zaufanych osób i instytucji na przedstawione przez propagandystę rozwiązanie), apelowanie do autorytetu (przytoczenie opinii osób cieszących się prestiżem w społeczeństwie), ludowość (nawiązanie opartych na zaufaniu relacji $\mathrm{z}$ odbiorcami poprzez stworzenie wizerunku polityka wywodzącego się z mas), tasowanie kart (selekcja faktów, zawierająca konkretną interpretację), owczy pęd 
(apelowanie do „większości”, oparte na potrzebie przynależności do grupy) (Miller 5). Dana klasyfikacja została znacznie rozwinięta przez późniejszych badaczy i wzbogacona o nowe terminy. Niemalże wszystkie wspomniane techniki mają na celu kreowanie zhierarchizowanego obrazu świata, który dzieli się na sferę akceptowaną przez oficjalną propagandę oraz sferę deprecjonowaną. Powyższą opozycję odzwierciedla binarny koncept swój - obcy, sformułowany na fundamentalnym założeniu o dwoistej naturze struktury rzeczywistości (por. biel - czerń, dobro - zło). Jego potencjał manipulacyjny tkwi w egocentrycznym przekonaniu o przewadze własnego stanowiska. Z jednej strony komponent „obcości” odnosi się do konceptu „nieznanego", na podstawie którego budowane są konwencjonalne stereotypy i mity polityczne. $\mathrm{Z}$ drugiej zaś strony model ten ma charakter solidaryzujący, służy integracji przedstawicieli określonej społeczności.

Propaganda wykorzystuje także techniki manipulacji rozumianej jako szczególny rodzaj oddziaływania psychologicznego (Docenko 59). Z punktu widzenia językoznawstwa manipulacja jest traktowana jako rodzaj perswazji i wyraża się za pomocą określonych środków językowych. Obecnie nie istnieje ujednolicona klasyfikacja metod językowej manipulacji. Jedni badacze zaliczają do niej ocenę, negację, inni wymieniają figury stylistyczne, takie jak pytania retoryczne, eufemizmy, porównania. Niektóre techniki scharakteryzowała w swojej monografii Psychologia manipulacji rosyjska badaczka Wiera Kozłowa (Kozlova 29-31). W ramach podanej przez nią klasyfikacji wyróżnia się m.in.: truizmy (szablonowe, banalne stwierdzenia), założenia (konstrukcje если..., то..., как только...), konstrukcje paralelne (struktury чем..., тем..., насколько..., настолько...), wybór bez wyboru (przedstawienie adresatowi kilku możliwości, z których każda spełnia jego oczekiwania), prawo wyboru (stworzenie iluzji wyboru przy akcentowaniu właściwej opcji). Podane techniki wzbogacają tekst o treści implicytne (naddane) oraz służą jako narzędzie niejawnego oddziaływania na postawę odbiorcy zgodnie $\mathrm{z}$ interesem nadawcy.

Językowa manipulacja występuje również na poziomie przedstawienia informacji. Komunikat propagandowy, pełniąc funkcję informacyjną, prezentuje adresatowi fakty odpowiadające oficjalnej polityce państwa. W naukach lingwistycznych i społecznych zwykle wyróżnia się trzy strategie manipulacji informacją: zniekształcanie, zatajenie oraz selekcję informacji (Vusik 95). Każda z powyższych technik jest realizowana przy użyciu kombinacji środków z różnych poziomów języka. Ponadto $\mathrm{w}$ jednym tekście metody te mogą się uzupełniać. Obecnie zastosowanie technik manipulacji informacją obserwuje się m.in. w wypowiedziach polityków czy przedstawicieli mediów. Mimo że w mniejszym lub większym stopniu towarzyszą one wszystkim sferom ludzkiej działalności, szczególna aktywność ich stosowania przypada na okres kryzysów społecznych, przyczyniających się do powstawania systemów totalitarnych. 
W Związku Radzieckim propaganda była obecna nie tylko w dyskursie politycznym. Stworzony dla jej celów nurt socrealistyczny powielał, zgodne z przyjętą ideologią, motywy i wzorce osobowe. Okresem szczególnego rozkwitu sztuki propagandowej była II wojna światowa, kiedy to dokonała się ostateczna legitymizacja władzy radzieckiej. Pojawienie się wspólnego wroga w znacznym stopniu przyczyniło się do konsolidacji społeczeństwa i jednoznacznego określenia kierunków jego rozwoju. Niemal każdy obywatel ZSRR został sztucznie przydzielony do jednej z dwóch grup: walczących lub podejmujących pracę na potrzeby frontu. Powyższy podział znalazł odzwierciedlenie w tekstach agitacyjnych, zapełniających niejako dwie przestrzenie radzieckiej propagandy wojennej. W niniejszym zestawieniu analizie zostaną poddane najważniejsze cechy języka propagandy Okien TASS w zależności od grupy docelowej adresatów. Badanie pozwoli wykazać zasady funkcjonowania propagandy wykorzystującej język poezji do sprawowania kontroli nad zachowaniem społeczeństwa. W analizie przytoczę fragmenty utworów Okien TASS zaczerpnięte ze zbiorów Rosyjskiej Biblioteki Państwowej im. W.I. Lenina w Moskwie, Moskiewskiego Państwowego Muzeum Literatury Rosyjskiej im. W.I. Dala oraz Państwowej Galerii Sztuki w Permie.

Pierwszą grupę odbiorców przekazów propagandowych stanowią osoby będące w stanie podjąć bezpośrednią walkę na froncie. W przeciwieństwie do krajów Europy Zachodniej, w ZSRR dane komunikaty skierowane były również do kobiet mogących zasilić radzieckie oddziały wojskowe. Najważniejszą cechą tekstów w danej grupie jest dyrektywność służąca wywarciu nacisku na adresata. Może ona przybierać różne formy, takie jak rozkaz, prośba czy propozycja. Jednak w plakatach propagandowych redakcji TASS jej dominującą odmianą jest wezwanie, wyrażone za pomocą odpowiednich form czasownikowych.

Największą częstotliwością wyróżnia się zastosowanie imperatywu („бей врага”, „будь как они”, „не отступай”). Rzadziej występuje forma trybu oznajmującego czasu przyszłego o charakterze żądania („,очистим наш край”, „наших граждан вызволим”, „мы отомстим”), bezokolicznik („сражаться”, „не осрамиться”), a także zdania z predykatami „надо”, „необходимо”, „нужно”, „должен” („дозор нести должны”, „должны мы помнить”) oraz struktury apredykatywne („,общим фронтом - на врага”, „за землю русскую - вперед”). Formy te tworzą specyficzne hasła wprowadzane do struktury plakatów w postaci tytułów lub elementów tekstu zasadniczego.

Należy zaznaczyć, że w roli nadawcy komunikatów Okien TASS rzadko pojawia się partia lub jej lider. Cytowane w tekstach fragmenty oficjalnych zarządzeń i ustaw służą jedynie jako wstęp do bardziej szczegółowego, poetyckiego komentarza. Nadawcą jest najczęściej przedstawiciel społeczeństwa, równoprawny uczestnik wojennych wydarzeń, zwracający się do swoich rodaków. Zgodnie $\mathrm{z}$ daną techniką wszyscy uczestnicy sytuacji komunikacyjnej kierują się jedna- 
kowymi zasadami. Motywacją do podjęcia działań jest wspólne zwycięstwo nad wrogiem, bezpieczeństwo i dobrobyt narodu radzieckiego, a przede wszystkim obowiązek obywatelski. Jako że dyrektywność w danych tekstach rzadko wyraża się bezpośrednio w formie rozkazu, można mówić o próbie stworzenia swoistego kolektywu, ponoszącego zbiorową i indywidualną odpowiedzialność za przebieg wojennych wydarzeń.

Kolejną cechą języka propagandy, przejawiającą się w tekstach Okien TASS, jest stereotypizacja postaci wroga. Potrzeba jednoznacznego zdefiniowania obrońcy i agresora wiązała się nie tylko z zachęceniem ludności do walki, lecz także z dążeniem do zapewnienia komfortu psychicznego żołnierzom, pragnącym usprawiedliwić własne działania. W odpowiedzi na te potrzeby autorzy tekstów odwołali się do kreowania uproszczonych, stereotypowych obrazów, przedstawiających wybiórczo hiperbolizowane cechy wrogich narodów.

Technika stereotypizacji jest ściśle związana z metodą etykietowania, polegającą na przypisywaniu osobom lub zjawiskom stałych określeń. Nominacja w Oknach TASS oparta jest głównie na ironii, hiperboli i generalizacji, np. każdy mieszkaniec III Rzeszy pojawiający w wierszach nosi popularne w tym okresie imię Фpuu, w związku z czym żołnierze niemieccy nazywani są zbiorczo фpuųbl. Samo użycie liczby mnogiej w danym kontekście ma charakter pejoratywny. Jak zauważa Bralczyk, wyrazy o neutralnym zabarwieniu znaczeniowym w liczbie pojedynczej mogą nabrać znaczenia negatywnego w kontekście zbiorowym (Bralczyk 107). W formach pluralnych zatraca się indywidualność nominowanych osób, tworzących niejako jednorodną masę, w stosunku do której nie obowiązują zasady humanizmu.

Etykietki mogą odnosić się także do władz państw totalitarnych. W większości tekstów Okien TASS nazwisko niemieckiego przywódcy zastępowane jest zironizowanym określeniem фюрер, a włoskiego - дуче (okno nr 190: Дуче к фюреру летит / фюрер дуче говорит). Aktywnie wykorzystywane są także jednoznacznie wartościujące rzeczowniki. Adolfowi Hitlerowi przypisywana jest etykietka палач, Benitowi Mussoliniemu - хвастун, Josephowi Goebbelsowi - лжец, a szefowi rządu Vichy Philippe'owi Pétainowi - mpyc. Dane określenia powielane są w kolejnych utworach, całkowicie wypierając wyrazy o znaczeniu neutralnym.

Szczególnym rodzajem etykietek są zoologizmy, które w symboliczny sposób przedstawiają degradację postaci wroga do pozycji zwierzęcia. W wierszach Okien TASS najczęściej używanymi określeniami, odnoszącymi się do danej kategorii, są rzeczowniki собака, пес, волк, овцча, козел, свинья, горилла oraz акула. Nawiązują one do cech zwierząt utrwalonych w kulturze ludowej, których nosicielami są bohaterowie baśni i bajek. Animalizacja przeciwników pozwala na przeprowadzenie analogii pomiędzy ich stereotypowymi cechami a charakterystyką znanych typów bohaterów literackich. 
Procesowi zezwierzęcenia człowieka poświęcone są liczne utwory wojenne. Motyw ten wykorzystali m.in. Diemjan Biedny (Фаиистская ворона или эрзаипава - okno $\mathrm{nr}$ 457), Aleksandr Rochowicz (Наглядные пособия - okno $\mathrm{nr} 447$ ), a także mistrz radzieckiej satyry Samuił Marszak (Сверхскотоводство - okno $\mathrm{nr}$ 124). Na szczególną uwagę zasługuje tekst Marszaka Ammecmam зверости, zamieszczony w oknie $\mathrm{nr} 177$. W wierszu przedstawiono proces indoktrynacji młodego Niemca (Фрица) w celu uczynienia z niego elementu faszystowskiego mechanizmu terroru. Utwór skonstruowany jest jako dialog między egzaminatorem i studentem zdającym egzamin na „świadectwo brutalności” (ammecmam зверости). W tytule zastosowano technikę gry językowej, w której zmieniony zostaje komponent dojrzałość (зрелость) - główny cel procesu wychowania. W tekście dokonuje się kontaminacja utrwalonych stereotypów dotyczących narodu niemieckiego. Podkreślono m.in. zapał i pracowitość Niemców, które w tekście uległy ironizacji (Фриц aktywnie uczestniczy w procesie nauki, pozbawiającej go ludzkich cech). Wiersz konstytuuje także nowe stereotypy, zapożyczone później w pracach kolejnych autorów. Należą do nich przede wszystkim ślepe posłuszeństwo mieszkańców III Rzeszy, a także ich podatność na propagandę (фюрер мыслит за него). Cechy te, w konfrontacji z wyidealizowanymi charakterystykami mieszkańców demokratycznego państwa, którym na plakatach jest Związek Radziecki, wskazują na utratę podstawowych wartości człowieka. Odrzucenie ogólnie przyjętych zasad moralnych prowadzi do całkowitej bestializacji narodu.

Stereotypy o silnym zabarwieniu emocjonalnym nie wymagały logicznego uzasadnienia, powoływano się w nich na uczucia i wiarę w wyższość własnej nacji. Na tej samej zasadzie budowane są argumenty emocjonalne wykorzystywane jako narzędzie indywidualizacji postrzegania wydarzeń wojennych. Osobiste apele do adresatów jako jednostek odbierających wojnę przez pryzmat swoich uczuć i troski o bliskich, a także wyznających określone zasady moralne stały się głównym instrumentem manipulacji działaniami społeczeństwa.

W tekstach Okien TASS większość argumentów emocjonalnych budowana jest wokół konceptu rodziny, rozpatrywanego w dwóch podstawowych kategoriach - indywidualnej (najbliższa rodzina adresata) oraz zbiorowej (naród jest jak rodzina). W pierwszej kategorii dominują obrazy cierpiących żon i osieroconych dzieci wymagających obrony. Pojawia się również motyw rodziców kierujących swoich synów na front dla zachowania honoru rodzinnego. W drugiej kategorii podstawową jednostką jest naród przedstawiany jako wspólnota braci i sióstr pod przewodnictwem matki (ojczyzny) i ojca (Stalina). W tym przypadku pojęcie rodziny służy konsolidacji żołnierzy i przerzuceniu na nich odpowiedzialności za los rodaków. Przykładem podanej argumentacji jest wiersz Wasilija Lebiediewa-Kumacza (okno nr 814) przedstawiający monolog matki zachęcającej syna do 
podjęcia walki na froncie („Иди вперед, сынок, иди не уставая! / За близких отомсти, освободи сирот!"). Autorytet matki, która odprawiając odwieczny rytuał błogosławieństwa, nadaje wojennej misji syna mistyczny charakter, wykorzystany jest jako argument do podjęcia walki za rodzinę i całą wspólnotę narodową.

W wierszach pojawiają się wezwania do zemsty za cierpienia bliskich. Ich adresatami są radzieccy żołnierze przedstawieni jako moralnie nieskazitelni wojownicy stojący na straży sprawiedliwości. Charakterystyka Armii Czerwonej silnie kontrastuje z portretem nazistów dopuszczających się zbrodni na ludności cywilnej. Podany obraz, poprzez przeprowadzenie paraleli pomiędzy wewnętrznymi wartościami moralnymi a koniecznością reakcji na zło, służy mobilizacji do podjęcia aktywnej walki. W plakatach propagandowych prawda jest postrzegana jako pojęcie subiektywne, do którego prawo ma wyłącznie naród radziecki. Dana koncepcja legitymizuje przemoc wobec wroga jako destrukcyjnej siły, nad którą musi zwyciężyć tendencyjnie postrzegana sprawiedliwość.

Aktywizacja do walki może być także realizowana na poziomie manipulacji językowej. Spośród wielu technik manipulacyjnych najbardziej powszechną metodą jest zastosowanie pytań retorycznych. Ten klasyczny zabieg pozwala zaakcentować założenia niepodlegające negacji. Na przykład pytanie „Что может быть бессмертной славы краше?” z wiersza Aleksandra Żarowa Mama и Haтама zawiera implikaturę, zgodnie z którą odrzucona jest możliwość istnienia wyższej wartości niż pamięć o czynach wojownika. Niekiedy, poprzez formułowanie pytań retorycznych, manipulator stwarza jedynie iluzję wyboru, sugerując czytelnikowi właściwą opcję. Daną technikę ilustruje fragment wiersza Diemjana Biednego Под откос: „Сметем врага иль нет мы с нашего пути? - / Могло ли это быть вопросом!'”. Również w tym wypadku odpowiedź przecząca jest praktycznie niedopuszczalna, gdyż wiązałaby się z wykluczeniem adresata z grupy.

Innym przykładem konstrukcji niezaprzeczalnych są zdania zawierające negację. Ich egzemplifikację stanowi stwierdzenie Моряки не подведуm! z okna nr 630, cechujące się większą sugestywnością niż wyrażenia twierdzące Моряки помогут сzу Моряки справятся, jako że jego zaprzeczenie (czyli konstrukcja z podwójną negacją) stanowiłoby naruszenie zasad języka rosyjskiego. Negacji nie podlegają także wypowiedzi wykrzyknikowe z wiersza Молодая партизанка Wasilija Lebiediewa-Kumacza: „Как такую не прославить, / песню как не спеть о ней!". Zwroty te służą gloryfikacji postawy radzieckiej partyzantki, zawierają pośrednie wezwanie adresatów do pochwały i naśladowania jej czynów.

Jednym z podstawowych narzędzi manipulacji emocjonalnej jest metoda założenia. Służy ona wyrażeniu warunku lub motywacji do wykonania określonej czynności. Technika ta została zastosowana np. w wierszu Siemiona Kirsanowa z okna nr 555 rozpoczynającego się od słów: „Если семья тебе дорога, уничтожай врага". Element odwołania się do uczuć, połączony z kategoryczno- 
ścią warunku, wymaga od adresata podjęcia aktywnego działania. Przywołanie ogólnie przyjętych wartości poszerza krąg potencjalnych odbiorców mających związek z poruszaną w tekście kwestią.

Poza pytaniami retorycznymi, negatywnymi konstrukcjami i założeniami w wierszach Okien TASS wykorzystywane są również inne metody, takie jak konstrukcje paralelne (Чем крепче тыл, тем сильнее фронт), chwytliwe hasła (Победить иль умереть) сzy adaptacja wyrażeń frazeologicznych do kontekstu (Что посеешь, то пожнешь). Wszystkie powyższe techniki służą jako instrument pośredniej agitacji opartej na emocjonalnym oddziaływaniu na adresata. Umożliwiają one przekazanie implicytnych znaczeń, które w bezpośrednim wyrażeniu utraciłyby swój sugestywny potencjał.

Do pewnego stopnia różnią się techniki propagandowe zastosowane w tekstach skierowanych do osób pozostających na zapleczu wojennych wydarzeń. Do tej grupy należeli głównie członkowie kołchozów oraz pracownicy zakładów dostosowujących produkcję do potrzeb militarnych. Pomimo aktywnej kampanii likwidacji analfabetyzmu (ros. ликбез - 'ликвидация безграмотности у населения') i innych działań mających na celu ułatwienie dostępu do edukacji, większość mieszkańców ZSRR w tym okresie nie otrzymała odpowiedniego wykształcenia. Dlatego też język utworów wierszowanych kierowanych do danej grupy podlegał znacznej symplifikacji. Występowanie adresata zbiorowego, posługującego się prostym językiem, doprowadziło do powstania specyficznego stylu, w którym dominującą rolę odgrywało: słownictwo potoczne o zabarwieniu neutralnym (портки, душегубка, лезть), w tym związki frazeologiczne (дать тягу, пойти насмарку, потянуть ноги), wykrzykniki (ей богу!, ату его!), deminutiwy (нянечки, деревушка), zapożyczenia (kanym - niem. kaputt), słownictwo potoczne zawierające pejoratywną ocenę (буржуй, холуй, забияка, пройдоха) oraz wulgarne słownictwo potoczne (всыпать, сволочь, урод, изверг, морда, голодранеи, сукин сын).

Inwektywność to jedna z najbardziej charakterystycznych cech języka Okien TASS. Pogardliwe określenia wrogów pojawiają się w większości wierszy o charakterze satyrycznym. Słownictwo potoczne dominuje w takich gatunkach jak baśnie czy bajki. W wyniku zwiększenia agresywności stylu destrukcji uległa funkcja estetyczna utworów. Środki wyrazu artystycznego poddane zostały uproszczeniu. Niemniej jednak obniżony styl wierszy Okien TASS decyduje o ich dostępności dla szerokiego grona odbiorców, co ma związek z taką techniką propagandy jak ludowość. Redukując dystans pomiędzy nadawcą a adresatami, stwarza się iluzję istnienia wspólnoty, buduje zaufanie do rządzącej partii. Interpretacyjna jednoznaczność i wysoka ekspresywność języka zapewniają silne oddziaływanie na odbiorców.

Ważnym środkiem mobilizującym do działania jest także ustanowienie binarnej opozycji swój - obcy, zbudowanej na antytezie. Zgodnie z daną koncepcją 
rzeczywistość dzieli się na dwa przeciwległe bieguny odpowiadające ontologicznym pojęciom dobra i zła. Antyteza swój - obcy realizuje się na dwóch głównych płaszczyznach obejmujących cechy przedstawicieli narodów biorących udział w wojnie, a także charakterystykę całych systemów gospodarczych.

W ramach pierwszej kategorii idealizuje się żołnierza radzieckiego i karykaturalizuje niemieckiego agresora. Obrońców ZSRR cechują takie przymioty, jak uczciwość, odwaga, męstwo i wytrwałość. Z kolei najeźdźców charakteryzuje okrucieństwo, niemoralność i tchórzostwo. Daną opozycję odzwierciadlają słowa wiersza Aleksandra Rochowicza z okna nr 445: „У пьяных гитлеровский рож / один закон - разбой, грабеж. / У нас воюет весь народ. / Партизан огонь ведет". Negatywnej ocenie podlegają także nacje współpracujące z Niemcami. W konsekwencji podkreślane są imperialistyczne ambicje Włochów, niezdecydowanie Rumunów przedstawianych jako marionetki Hitlera, a także konformizm Francuzów. W późniejszych plakatach do kategorii „swój” zostały przyłączone kraje Ententy. Są nimi głównie Stany Zjednoczone i Wielka Brytania, przedstawiani jako sojusznicy w walce pod przywództwem ZSRR. Pozytywny wizerunek narodu amerykańskiego zmieni się radykalnie pod wpływem reformowania radzieckiej propagandy w okresie zimnej wojny.

W ramach opozycji swój - obcy w szerszym kontekście skonfrontowane zostały również systemy państwowe: socjalizm i kapitalizm. Socjalistyczna Rosja w Oknach TASS przypomina utopijny kraj, w którym społeczeństwo funkcjonuje na wzór idealnie zsynchronizowanego mechanizmu. ZSRR rozwija się pod opieką partii, której podstawowym zadaniem jest utrzymanie porządku i bezpieczeństwa. Z kolei władza III Rzeszy dąży jedynie do maksymalizacji swoich dochodów kosztem śmierci milionów ludzi. Merkantylny charakter ich polityki odzwierciedla zdanie z wiersza w oknie nr 513: „Кому война, кому доходы!”, które Diemjan Biedny przypisuje Adolfowi Hitlerowi. Podwójne użycie w danej frazie zaimka комy służy wyrażeniu antytezy (jedni cierpią w wyniku wojny, inni wzbogacają się). W państwie kapitalistycznym główną siłą sprawującą kontrolę nad ludnością jest umiejętnie prowadzona przez Josepha Goebbelsa propaganda. Wolność osobista człowieka ograniczona jest do minimum, co odzwierciedla się w silnej indoktrynacji ideologicznej społeczeństwa.

W istocie wprowadzenie do opozycji swój - obcy elementu ekonomicznego wskazuje na kontynuację rewolucyjnej propagandy Okien ROSTA. Teksty powtarzają wezwania do zniesienia niesprawiedliwego (burżuazyjnego) systemu, którego ucieleśnieniem jest III Rzesza. Na przeciwnym biegunie znajduje się ustrój socjalistyczny, gwarantujący równość społeczną. W zestawieniu swój- obcy socjalizm odnosi się do konceptu „swój” jako element definiujący naród rosyjski. Za tym stanowiskiem kryje się presupozycja wskazująca na to, iż system komunistyczny w Rosji jest swoistą konstantą, niepodlegającą zaprzeczeniu. Identyfi- 
kując się z narodem rosyjskim $\mathrm{w}$ walce $\mathrm{z}$ wrogiem, adresat utożsamia się jednocześnie z ideałami socjalistycznymi. Tym samym potencjał manipulacyjny Okien TASS rozszerza się również na obszary ideologii służące wzmocnieniu pozycji partii rządzącej.

Szczególną metodą propagandy, aktywnie wykorzystywaną w Oknach TASS, jest apelowanie do autorytetu. Technika ta może przybierać dwie formy: prezentację stanowisk popartych autorytetem rozpoznawalnych osób, a także ustalenie wzorców zachowań motywowanych czynami przeciętnych obywateli. Przywoływane w propagandowych tekstach „wzorce do naśladowania” stanowią impuls do podjęcia działań zgodnych z przyjętą ideologią.

W kontekście propagandy socjalistycznej podstawowym typem argumentacji powinno być odwołanie do autorytetu przywódców partii - Włodzimierza Lenina oraz Józefa Stalina. Jednak, jak już było wspomniane, mimo prób stworzenia mitu o bliskości wodza i ludu dystans między władzą a społeczeństwem nie pozwolił autorom wierszy traktować Stalina jako wzoru do naśladowania dla przeciętnego radzieckiego żołnierza czy robotnika. Z powyższych względów utwory Okien TASS kreują autorytet bohaterów wielkiej wojny ojczyźnianej wyłonionych z prostej ludności. Są wśród nich wizerunki stachanowców, żołnierzy, którzy oddali życie w walce za ojczyznę, sióstr miłosierdzia niosących pomoc na froncie, kobiet zastępujących mężczyzn w fabrykach. Wiersze zawierające te motywy wzorowane są na hymnach opowiadających historie rozsławionych obywateli i gloryfikujących ich aktywność. Propaganda okresu II wojny światowej charakteryzuje się mitologizacją czynów konkretnych osób, takich jak operator frezarki Monakow, żołnierz Armii Czerwonej Aleksandr Matrosow czy snajperki Natalja Kowszowa i Marija Poliwanowa. Odwołanie się do danych autorytetów stwarza przekonanie, że każdy może przyczynić się do zwycięstwa w wojnie.

Niekiedy w tekstach pojawiają się nazwiska zaczerpnięte z rosyjskiej historii i literatury. Propaganda wielkiej wojny ojczyźnianej powołuje się na postacie kultury rosyjskiej, które pozostały żywe w świadomości ludzi nawet po zwycięstwie rewolucji. Należą do nich bohaterowie słynnych wojen (Aleksander Newski, Piotr Wielki, Aleksandr Suworow), postacie z eposów i baśni (trzej mocarze), a także rosyjscy poeci i malarze (Aleksandr Puszkin, Michaił Lermontow, Ilja Riepin). Niektóre teksty poetów epoki romantyzmu przywołane są na plakatach w formie cytatów korelujących ze współczesnymi utworami (np. w oknie nr 427 przedstawiającym fragment wiersza Michaiła Lermontowa Бородино, którego kontynuację stanowią strofy Aleksieja Maszystowa: „Сто тридцать лет прошло и снова / в просторах поля рокового / кровавый грянул бой”). Apelowanie do autorytetów z historii Rosji ma wzbudzić poczucie dumy z przynależności do narodu o bogatym dziedzictwie kulturowym, którego kontynuacją jest społeczeństwo Związku Radzieckiego. 
Kolejną techniką propagandową, skierowaną do ludności niepodejmującej bezpośredniej walki, jest modyfikacja informacji o wydarzeniach wojennych. Wiadomości zawarte w Oknach TASS prezentowane są zgodnie z radziecką propagandą okresu II wojny światowej, w związku z czym podlegają manipulacyjnym transformacjom, do których należą selekcja, zatajenie oraz zniekształcenie.

Informacje zawarte w nagłówkach plakatów najczęściej odnoszą się do najbardziej aktualnych wydarzeń na froncie. Ich tematyka koncentruje się wokół sukcesów militarnych Armii Czerwonej i klęsk oddziałów niemieckich. Wiadomości o niepowodzeniach wojsk radzieckich podlegają eufemizacji lub zostają całkowicie utajone. Nagłówki mogą zawierać krótką informację (Париж освобожден!, Блокада прорвана!) lub stanowić bardziej rozbudowany opis wojennej sytuасјі (Наши войска, развивая наступление, вышли на нашу государственную гранииу - реку Прут), nierzadko z elementem oceniającym (Антонеску в беде).

Z wyrazistymi nagłówkami Okien TASS korelują fragmenty tekstów prasowych. Przy ich cytowaniu bardzo często pomijane jest źródło informacji. Teksty opatrzone są podpisem: из газет, из радиопередач. Wiadomości podane na plakatach nie są autoryzowane. Brakuje nazwisk polityków ogłaszających nowe prawa i generałów wydających rozkazy. Zniekształcone są również dane liczbowe, przedstawiające hiperbolizowane wartości (np. 126 radzieckich snajperów pokonało ok. 2000 żołnierzy niemieckich). Należy zaznaczyć, iż czynnikiem selekcji informacji w Oknach TASS był nie tylko ich potencjał informacyjny. Fragmenty te, relacjonując ironiczne, często absurdalne wydarzenia, stanowiły wstęp do poetyckich tekstów satyrycznych. Przykładem może być informacja, że berlińska policja zakazała nazywania psów nazwiskami faszystowskich polityków i następujący po niej wiersz Aleksandra Żarowa Собачья история (okno TASS nr 711).

Pełnię wyrazu autorzy Okien TASS uzyskiwali dzięki kontaminacji części informacyjnej i poetyckiego komentarza. Na plakatach wszystkie elementy uzupełniają się, tworząc efekt synergii. Podane informacje służą stworzeniu wyidealizowanego obrazu rzeczywistości, zaszczepieniu w społeczeństwie wiary w przewagę Związku Radzieckiego. W ten sposób formułowano propagandę zwycięstwa, będącą swoistym fenomenem komunistycznego systemu totalitarnego.

Utwory poetyckie Okien TASS wyróżniały się silnym ukierunkowaniem na adresata. Dzięki swojej uproszczonej treści i dynamicznej formie stały się ważnym instrumentem wojennej propagandy, mającej na celu kształtowanie wzorców zachowań oraz manipulowanie opinią publiczną. Obejmowały dwie przestrzenie społeczne Związku Radzieckiego, dostosowując swoją treść do odpowiedniej grupy odbiorców.

Teksty skierowane do potencjalnych żołnierzy zawierały bezpośrednie wezwanie do obrony ojczyzny oraz rodziny. Ich najważniejszym narzędziem ma- 
nipulacyjnym były argumenty emocjonalne oraz technika stereotypizacji obrazu wroga, pozwalające niejako zaprogramować w świadomości adresatów potrzebę walki z agresorem, będącym ucieleśnieniem rozkładu moralnego i ślepego posłuszeństwa wobec władzy. Jednocześnie w przeciwieństwie do propagandy krajów Europy Zachodniej radzieckie utwory rzadko przedstawiały wroga jako realne zagrożenie, mogące przyczynić się do upadku komunistycznej potęgi. Wizerunek przeciwnika poddawany był silnej karykaturalizacji. Poprzez degradację jego pozycji wzmacniano wiarę $\mathrm{w}$ zwycięstwo żołnierzy radzieckich jako nosicieli jedynych słusznych wartości. Idee i wzorce osobowe były zaszczepiane w świadomości walczących za pomocą rozmaitych technik manipulacji językowej. Prowadzona w ten sposób propaganda wykorzystywała do osiągnięcia zamierzonych celów jedną z najważniejszych potrzeb człowieka - przynależności do grupy.

Odmienne techniki propagandowe stosowano w utworach skierowanych do osób pozostających na zapleczu działań wojennych. Podstawowym celem propagandy w tej grupie była motywacja do pracy na rzecz frontu. Autorzy tekstów Okien TASS posługiwali się językiem potocznym, zrozumiałym dla szerokiej grupy odbiorców. Kreowali wizję świata podzielonego na dwa bieguny, pozostające ze sobą w ścisłej opozycji. Jednocześnie budowali więź pomiędzy ludnością pracującą a podejmującymi walkę rodakami, ukazując drogę do osiągnięcia wspólnego zwycięstwa. W celu stworzenia odpowiednich postaw społecznych powoływali się na szanowane autorytety lub kreowali nowe wzorce osobowe. W przedstawianej przez nich rzeczywistości system komunistyczny zapewniał wszystkie środki niezbędne do pomyślnego zakończenia konfliktu. Podtrzymanie propagandy zwycięstwa wymagało jednak manipulowania przepływem informacji, w tym zatajania wiadomości o klęskach Armii Czerwonej. W powyższy sposób utwory agitacyjne Okien TASS wypełniały zadania wyznaczone przez komunistyczną partię rządzącą. Były silnym narzędziem perswazji, służyły do mobilizowania ludności oraz stanowiły osobisty wkład radzieckich poetów w zwycięstwo w II wojnie światowej.

\section{Bibliografia}

Bralczyk, Jerzy. O języku propagandy i polityki. Warszawa, Wydawnictwo Trio, 2007.

Docenko, Evgenij L. Psihologiâ manipulâcii: fenomeny, mehanizmy i zaŝita. Moskva, Izdatel'stvo MGU, 1997.

Dubisz, Stanisław, red. Uniwersalny słownik języka polskiego. T. 3. Warszawa, Wydawnictwo PWN, 2009.

Kamińska-Szmaj, Irena. „Propaganda, perswazja, manipulacja: próba uporządkowania pojęć”. Manipulacja $w$ języku. Red. Piotr Krzyżanowski, Paweł Nowak. Lublin, Wydawnictwo Uniwersytetu Marii Curie-Skłodowskiej, 2004, s. 13-27. 
Konopackaâ, Tat'âna N., Lûbov' È. Medne. „Ostroe pero, stihi sovetskih poètov v central'nyh Oknah TASS". Sovetskie pisateli na frontah Velikoj Otečestvennoj vojny. Red. Aleksej N. Dubovikov, Nikolaj A. Trifonov. Moskva, Nauka, 1966, s. 444-451.

Kozlova, Veronika A. Psihologiâ manipulirovaniâ. Orel, MOO ABIV, 2014.

Lippmann, Walter. Public opinion. New Brunswick-London, Transaction Publishers, 1998.

Maslennikov, Viktor A. Okna TASS 1941-1945. Moskva, Kontakt-kul'tura, 2007.

Miller, Clyde Raymond. „Techniques of Propaganda”. Propaganda analysis, 1. Red. Eduard C. Lindeman. New York, Institute for Propaganda Analysis, 1938, s. 5-8.

Vojtasik, Leslav. Psihologiâ političeskoj propagandy. Per. s pol'skogo âzyka Vladimir N. Porus. Moskva, Progress, 1981.

Vusik, Anna L. „Rečevaâ manipulâciâ - vid âzykovogo vozdejstviâ v političeskom diskurse”. Âzyk i pravo: aktual'nye problemy vzaimodejstviâ. Vyp. 5. Red. Vadim Û. Melikân. Rostov-na-Donu, Donskoe knižnoe izdatel'stvo, 2015, s. 92-99. 